\title{
unindra
}

Universitas Indraprasta PGRI

Address: Jl. Nangka No. 58 C (TB. Simatupang), Kel. Tanjung Barat, Kec. Jagakarsa, Jakarta Selatan 12530, Indonesia. +62 (021)

7818718 - 78835283; url: www.unindra.ac.id; cultural.syndrome@unindra.ac.id

\section{The Ergonomics of the Islamic Ablution: Exploring Considerations for the Elderly in the Mosque}

Sarah Aliya Che Hasbi ${ }^{1}$, Sufian Hamat ${ }^{2}$

Kulliyyah of Architecture and

Environmental Design, International

Islamic University Malaysia ${ }^{1,2}$

Correspondence regarding this article should be addressed to:

Sarah Aliya Che Hasbi, sarahaliya97@gmail.com

\section{Article History}

Received : 30-05-2020

Revised : 04-07-2020

Accepted : 29-07-2020

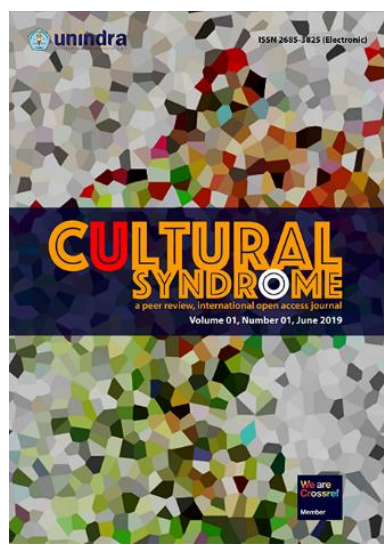

Cultural Syndrome

a peer review, internasional open access journal e-ISSN: 2685-3825

Editor: (D)Ahmad Faiz Muntazori

Publication details, including author guidlines https://journal.unindra.ac.id/index.php/cusy/ about/submissions\#authorGuidelines

\section{How to cite this article (MLA 8th)}

Che Hasbi, Sarah Aliya and Sufian Hamat. "The Ergonomics of the Islamic Ablution: Exploring Considerations for the Elderly in the Mosque." Cultural Syndrome, Vol.2, No.1, 2020, pp. 59-77, https://doi.org/10.30998/cs.v2i1.323

\section{The readers can link to article via https://doi.org/10.30998/cs.v2i1.323}

SCROLL DOWN TO READ THIS ARTICLE

Universitas Indraprasta PGRI (as Publisher) makes every effort to ensure the accuracy of all the information (the "Content") contained in the publications. However, we make no representations or warranties whatsoever as to the accuracy, completeness, or suitability for any purpose of the Content. Any opinions and views expressed in this publication are the opinions and views of the authors, and are not the views of or endorsed by Universitas Indraprasta PGRI. The accuracy of the Content should not be relied upon and should be independently verified with primary sources of information.

\section{(c) (i) \$}

This work is licensed under a Creative Commons Attribution-NonCommercial 4.0 International License.

Copyright by Sarah Aliya Che Hasbi \& Sufian Hamat (C 2020)

\footnotetext{
The authors whose names are listed in this manuscript declared that they have NO affiliations with or involvement in any organization or entity with any financial interest (such as honoraria; educational grants; participation in speakers' bureaus; membership, employment, consultancies, stock ownership, or other equity interest; and expert testimony or patent-licensing arrangements), or non-financial interest (such as personal or professional relationships, affiliations, knowledge or beliefs) in the subject matter or materials discussed in this manuscript. This statement is signed by all the authors to indicate agreement that the all information in this article is true and correct
} 


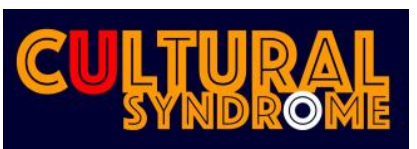

Vol.2, No.1, 2020, pp. 59-77

e-ISSN: 2685-3825

https://doi.org/10.30998/cs.v2i1.323

\title{
The Ergonomics of the Islamic Ablution: Exploring Considerations for the Elderly in the Mosque
}

\author{
Sarah Aliya Che Hasbi ${ }^{1}$, Sufian Hamat ${ }^{2}$ \\ Kulliyyah of Architecture and Environmental Design, International Islamic \\ University Malaysia 1,2
}

\begin{abstract}
A general observation on the state and condition of the ablution area at some mosques in the country has pictured the place as slippery and unsafe and not properly used and maintained. This has led to the assumptions that the design of the place had not thoroughly considered the ergonomic factors and right anthropometric of the users which has created discomfort in positioning oneself and accessing the fixtures during the act. The impact of the problems has never been rationalized and always overlooked particularly on how it may affect the elderly group that is has become very common and being repeated in the provision of the ablution area in other mosque's design and development. In consideration of the pressing issues and needs for an appropriate ablution area as part of safety and cleanliness measures at Mosque or Surau, the design of the facility must be emphasized and be based on the needs and physical abilities of the users. This particular study on the ablution area is necessary as it has uncovered salient and common problem of the current design of the place. The methodology selected for the study was a combination of several methods. It encompassed onsite observation on the practical use and performance of the ablution area, interview survey on users' practical experience and design assessment focusing on the ergonomic and anthropometric considerations of the place through measured drawing method. The results were triangulated to determine the overall performance of the present design of ablution area in facilitating spiritual obligation of the people. For the purpose, three different mosques in Kuala Nerus district namely Masjid UNiSZA (Universiti Sultan Zainal Abidin), Masjid UMT (Universiti Malaysia Terengganu) and Masjid Tok Jembal were selected as case studies. The study on the 3 sites of ablution area has displayed results indicating problems generally based on the location and proximity of water faucet and seating provision at the area which apparently were not based on the right ergonomic. This has created discomfort to the users and leaving messy and slippery ground after use.
\end{abstract}

Keywords: Ablution Workstation, Elderly, Ergonomic, Design, Mosque

Correspondence author: Sarah Aliya Che Hasbi, sarahaliya97@gmail.com,Terengganu, Malaysia

(c) (i) \$

This work is licensed under a CC-BY-NC 


\section{Introduction}

Based on UN World Population Prospects, Malaysia population reached 32.37 million which increasing around 0.42 million from 2019. According to them, the growth rate in 2020 is $1.30 \%$. "This is significantly lower than its rate in 2000 , which was $2.51 \%$. This decrease in the population growth rate is expected to continue in the next few decades, slowing down population growth until the numbers plateau and eventually decline." (UN World Population Prospects). This growth rate will cause a declination of population and increasing the aging population in Malaysia. According to the Ministry of Health, Labor and Welfare of Malaysia (MHLW), elderly refers to the people who are 60 years and above. Related to this issue, Malaysia need to comply the demands from elderly since the growth become higher than previous years. Aman et al. in their article stated that Rodrigues Barbosa mentioned elderly having one or more illnesses other than having movement or functional problem. In Malaysia, elderly people normally are quite active especially related to the religious activities. Due to the improvement of healthcare services, the number of active elderly people rising which they become prefer to live independently (Fitzpatrick). Therefore, the development of facilities needs to match their capabilities and abilities while they performing their daily activities especially praying facilities (Dawal et al.).

\section{Mosques and Design issue of ablution area}

Mosque is a spiritual place of peace where people of Islamic faith would come together to worship Allah Almighty. The view of large group of people of all walks of life exercising their religious obligation and spiritual passion is a display of unity of people of the same faith at its best. The philosophy in the setting and site planning and architectural design of the building and interior detailing concerning the volume of the space, the lighting, the shades of color, detailings and materiality of the place resonate with spirituality and peacefulness which may instil sense of humility and self conviction on the notion of the oneness of God. In addition to the aspects of design that may evoke the feeling of humility toward the Greatness of Allah, the design of the mosque should embody not only the requirements of prayer, but also the spirit and universality of Islam. In relation to that, in Islam, cleanliness is highly emphasized and a clean physical self is necessary before performing religious obligation. For that matter, an act of ablution or performing ' $W u d h u^{\prime}$ ' is a requirement before a person can perform prayers.

In Malaysia, an ablution area is a requirement, and thus, provision, for every praying facility including mosques, surau, and musolla. Both praying area and ablution area usually are spatially connected and linked between each other. Mynatt and Rogers (2001) identified that most designs of praying facilities developed by certain countries does not have proper designs in terms of supporting spaces, meanwhile they only focus solely on the appearance (Dawal et al.).

Mosques are also frequented by the community and particularly the elderly. In Islam, one is taught to consider the hereafter, thus particularly community members of a more senior age group will frequent the mosques. Yet one generally observes the 
hazardous nature of ablutions areas, which are slippery due to the splashing of water. According to the Mokhtar "Design Standards for Muslim Prayer Facilities within Public Buildings", "Unfortunately, the architectural designs of prayer facilities are frequently deficient, which results in spaces being uncomfortable and unsafe. This is particularly true for international design offices that are asked to design public buildings in cities such as Dubai, Abu Dhabi and Doha. Apparently, the reason for deficient design is the lack of adequate standards that guide designers' decision-making." He then continued, he as a well-experience architect, a space user and scientific observer need to study welldesigned spaces in order to identify strengths of that particular areas, and integrate the hypothesis as what he found (Mokhtar "Design Standards for Muslim Prayer Facilities within Public Buildings"). Besides, he also recommended to study on unsuccessfully designed spaces and point out the weeknesses and suggest their prevention. Meanwhile, Anwar mentioned, "the performance of existing spaces designed for the act/function of ablution differs according to the quality of the spatial design of the ablution facility." (Mokhtar "Design Standards for Muslim Prayer Facilities within Public Buildings")

Earlier studies have shown most of the ablution facilities in mosques are inadequately designed especially on the practical used that equality between physically reasonable needs while performing ablution." Dawal stated that, Malaysia was set a guideline which called as Malaysia Standard as a reference for developer and designer to build public facilities which can be user-friendly for vulnerable group such as elderly and disabled population (Dawal et al.). They continued "Therefore, it is necessary for praying facilities designer to promote an adequate environment for the elderly and disabled, considering their needs, capabilities, abilities and limitations." Meanwhile Julaila Abdul Rahman stated that ablution platform and its area are essential to be developed in ergonomic, user-friendly and practical needs as to full-filled users' preferences with comfortable and safe condition. They also agreed that most of the mosques' ablution platforms are not user-frindly and ergonomic based on the previous studies that had been done by experts (Abdul Rahman et al. $)$. This issue needs to take seriously since it is sensitive for elderly in health aspect since they are also part of the community that using this facility.

\section{Ablution sectional design: current baselines and practices}

Each of these issues make an important contribution to an 'improved' design understanding for the designer and also the developer. Currently, a better baselines and practices has been developed and full-filled the requirements of ablution area's preferences. Fig 1 below illustrate the ablution sectional design with appropriate design standard and guidelines. The measurement of the ablution area is following the user's preferences which including ergonomic, safety and user-friendly. This measured drawing was prepared by Ahmed Adel under Saudi F15 Fleet Mordenization Program. This mosque located at King Khalid Air Base (KKAB) which is an airbase of Royal Saudi Airforce (RSAF) located in Khamis Mushayt, Saudi Arabia. The project was dated in year 2015. 


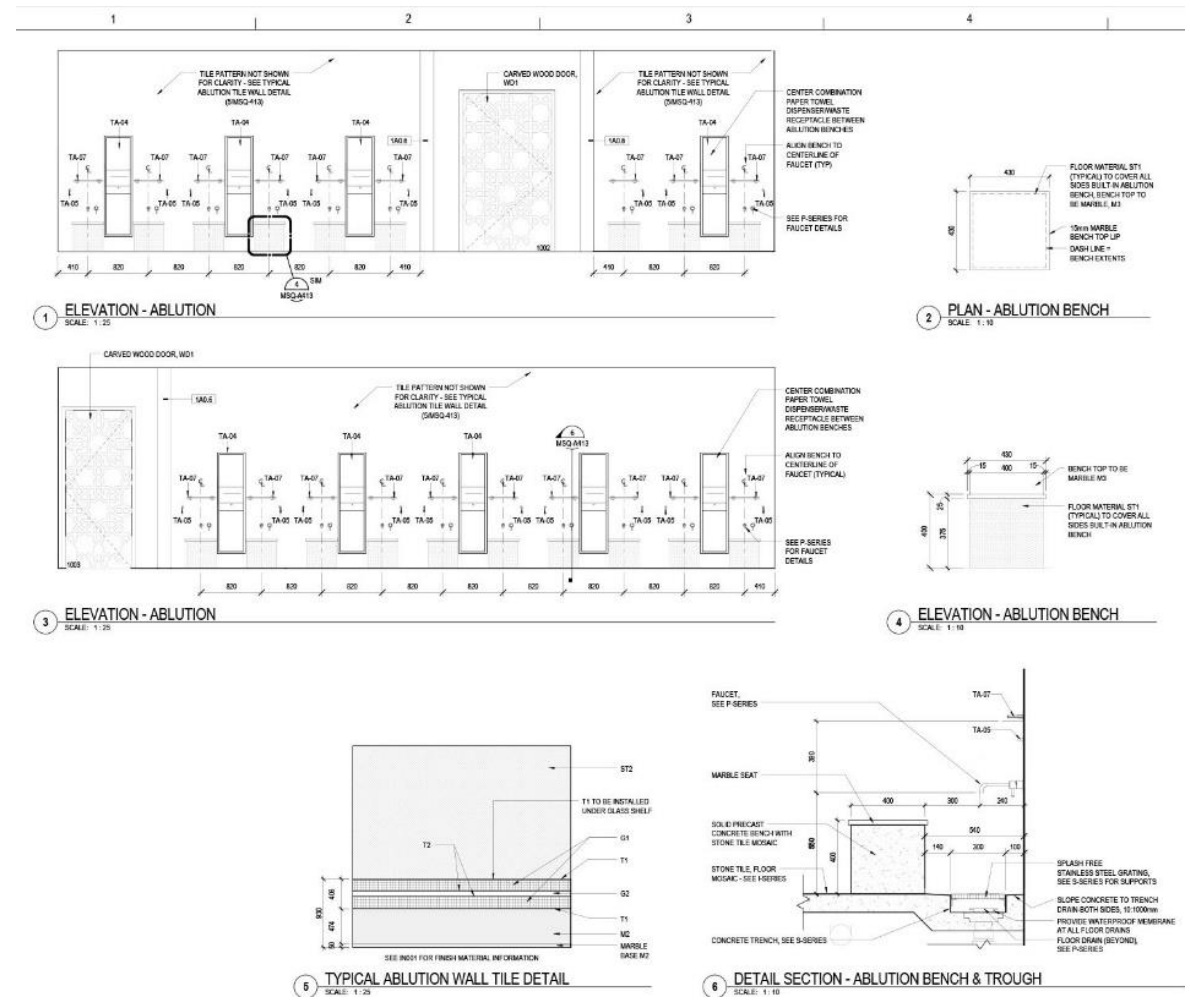

Fig 1 Ablution design details (Mokhtar "Design Standards for Muslim Prayer Facilities within Public Buildings")

From the elevations and details, it shows that every station was provided with a seat for the user. Not only that, these also indicate the appropriate space and separations between the location of the seating provision and the water faucet. Therefore, the user might experience less exposure to the water splash while taking the wudu'. Besides, they also provided a proper height of handrail user can easily grab while they want to wash their legs and helping them to getting up from the seat. It can be seen from the measured drawing that this ablution workstation was very detailed and focus on the user's safety and ergonomic. Instead, not only elderly will be happy with this kind of design, but people with disabled (PWDs) also can use this space comfortably.

\section{Case Study: BECC Mosque, Denver}

Besides of previous design in Saudi Arabia, this study also will highlight few case studies as a guideline of current baselines and practices. This case study is a very unique project which is a renovation of an existing church building into a mosque. The building was dated in mid-50s and located in 3550 Sheridan Boulevard, Denver. According to the Pel.Ona which is the architects and urbanists of the project, the building is not only become a mosque, but they also want to make this building as educational and community center for the Bosnian Educational Cultural Center of Colorado (BECC). The design was aim to provide a functional, warm and fascinating space for the Bosnian community. The aim was to enable the community to easily purify and pray in the 
mosque, and show the identity of the BECC plus keep the operational costs low so that the refurbishment are attainable and within the budget.

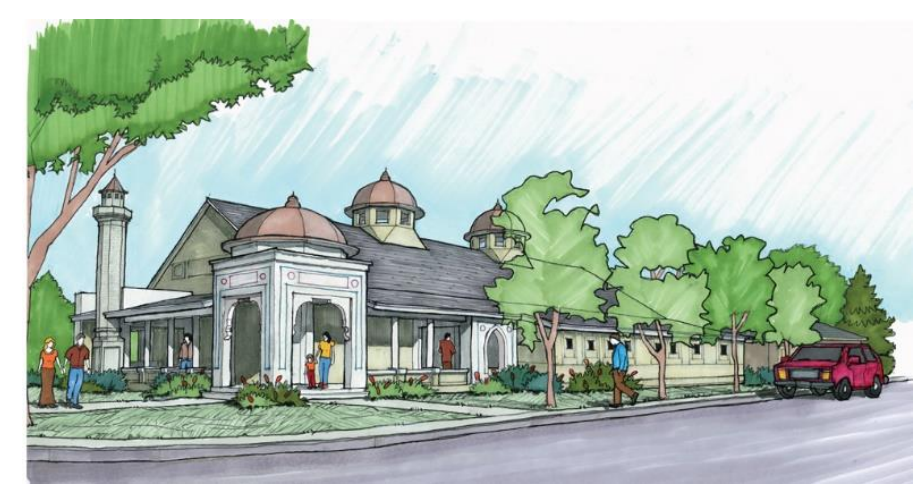

Fig. 2 A perspective of BECC Mosque (Pel-Ona Architects \& Urbanists)

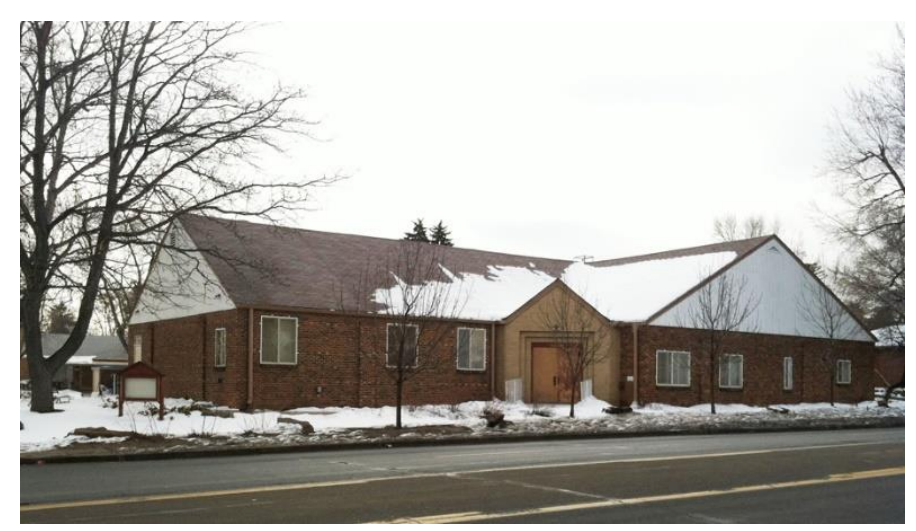

Fig. 3 Existing building before the renovation (Pel-Ona Architects \& Urbanists)

Related to this study, the ablution area in this BECC Mosque is interesting and unique because they manage to combine the concept of experiencing water elements similar to the traditional mosque environments of the past and the ergonomically conscious system of this workstation. 


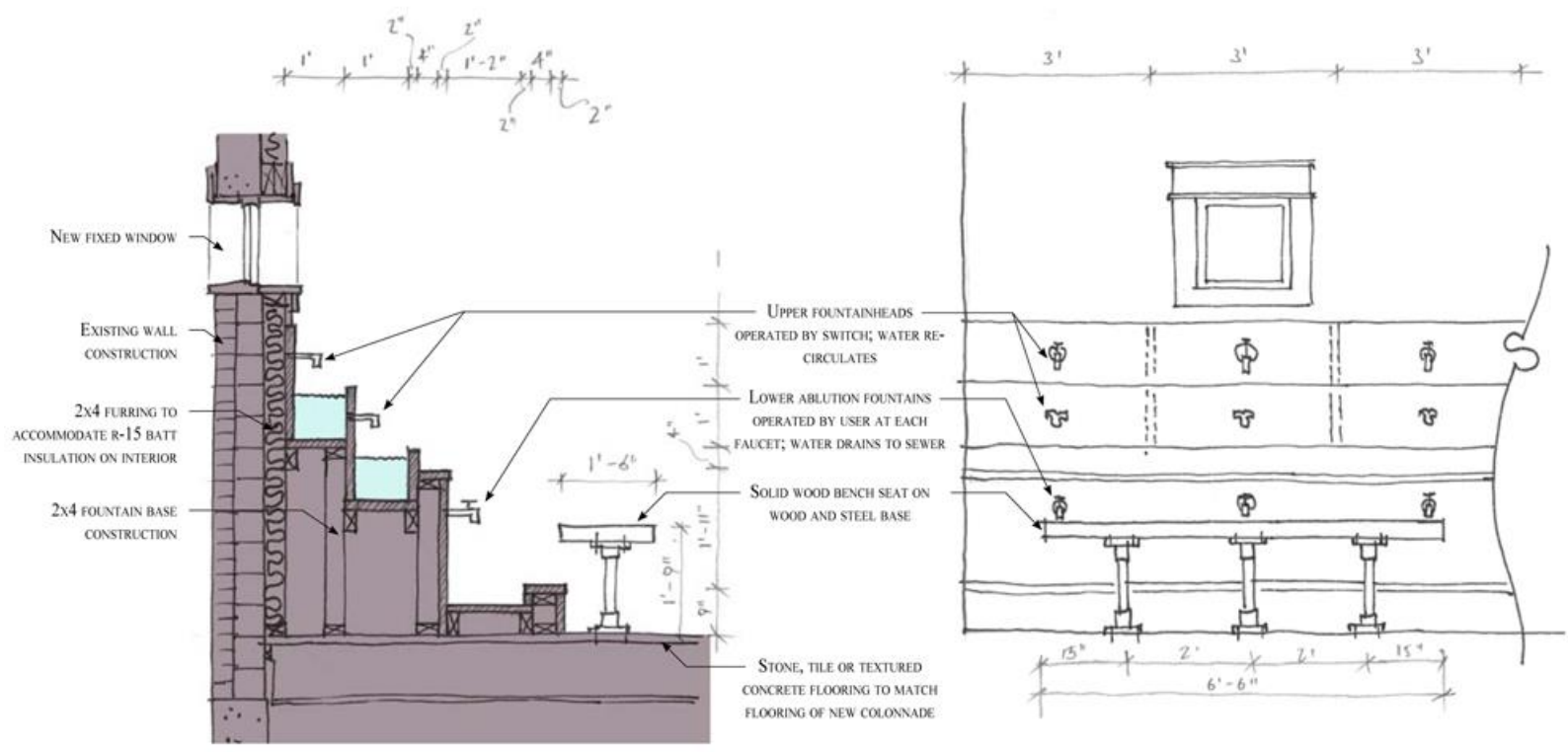

Fig. 4 Sketches of ablution sectionl design of BECC mosque (Pel-Ona Architects \& Urbanists)

"Ablution fountains are important symbolic elements in mosques and are usually celebrated as such. Here, cascading fountains will transform the sound landscape in the main entry lobby before entering the main mosque space. The fountains re-circulate water to reduce waste, while a dedicated tier provides fresh water for ablution on demand." (pel.ona, n.d). This brilliant idea is not only can save the water and maintain the environment, but also develop a new invention in Islamic world and perspectives. Fig. 5 illustrate the technical drawing of the proper design in BECC Mosque.
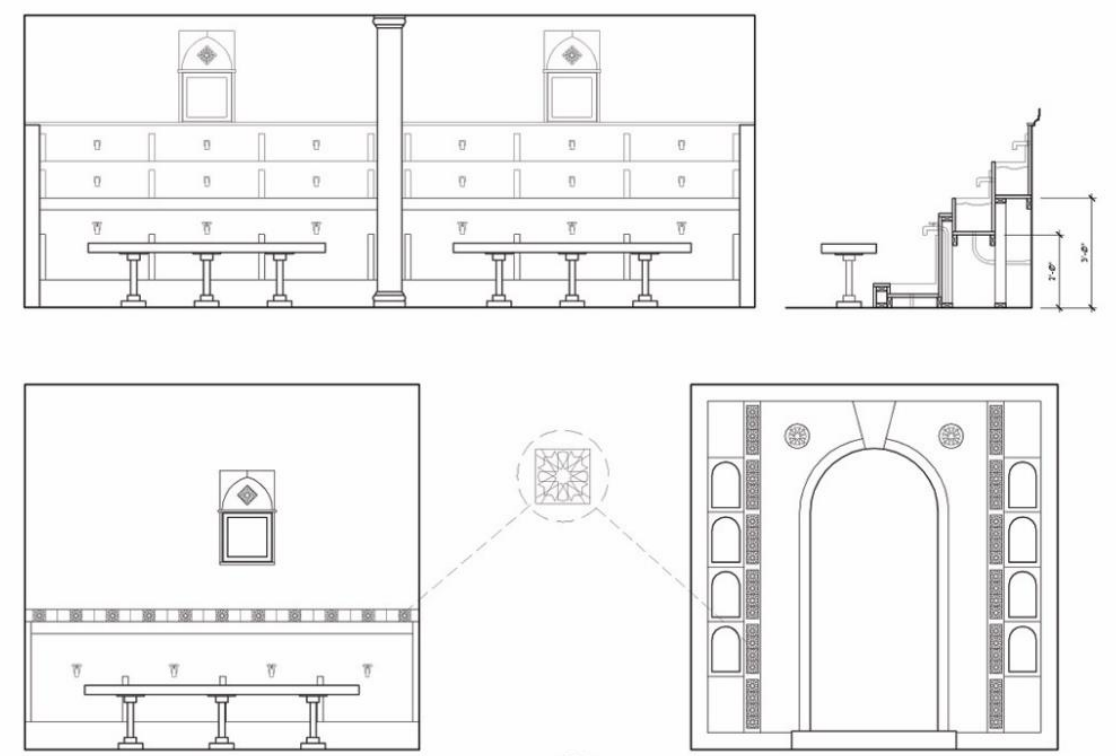

Fig. 5 ablution area design details (Pel-Ona Architects \& Urbanists) 
From the figure, it can be seen that the ergornomical considerations and proper measurement was applied on the design in order to produce an ergonomic and accessible space for disable and able people. Pel.ona also mentioned that the main key point of the building is to change an abandoned church into a prospering mosque within the limited budget only. Therefore, many of elements were inspired by traditional buildings, which were at human scale, and that they mainly focus for paid are focal point of prayer, the Mihrab, and also main entrance and Fountain of Ablution.

\section{Case Study: Auto Wudu Washers (AWW)}

Due to the demand of Muslims and mosques worldwide and public awareness raised in publications to highlight this issue, the invention of Auto Wudu Washers (AWW) was innovated by a company by using vision sensor. As highlighted by Adnan Rachmat Anom Besari, the 'wudhu' machine was invented and designed by Athony Gomez who is the Chairman of Managing Director of Australian AACE Worldwide PTY Ltd. Company. "He decided to produce a sophisticated wudu' machine based on stateofthe-art technology to ensure water and time efficiency." (Besari et al.). Figure 1 below show the Auto Wudu Washers (AWW). This machine shows that our community become more aware on this issue and many studies were conducted to promote this ablution machine in Malaysia. Instaed of providing an ergonomic and user-friendly machine towards the users, this machine also promotes the sustainable usage of water while taking the ablution.
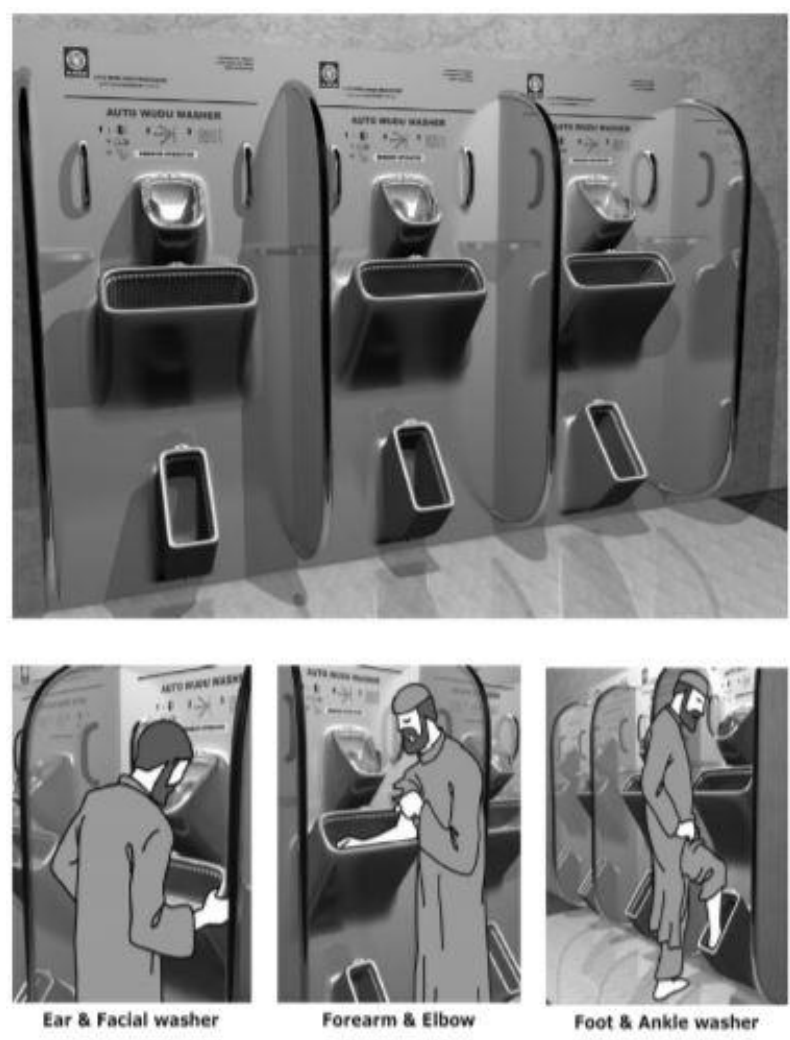

Fig. 6 Auto Wudu Washers $@($ AWW) (Besari et al.) 
Adnan Rachmat Anom Besari mentioned that this machine (Figure 1) was designed not to require any taps because it is operated by infrared sensors based on Autralia technology. "Main features of this machine are state of the art technology, washes and dries automatically, clean and hygienic, no water spillage, facilitates quick efficient washing, prevents overcrowding in wash rooms, ergonomic design, user friendly, low maintenance, easy installation. This machine made in Australia (U.S Patent Pending) Endorsed and approved by the Islamic Council of New South Wales, Australia (Member of the Arab Chamber of Commerce Australia)."(Besari et al.). Meanwhile, Maher (in Besari et al.) said "The Islamic Council of Australia has issued a fatwa approving the new machine." Based on this innovation, the technology does require the needs of environmental design yet the implementation of this machine in Malaysia is still less and the problem of non-ergonomic and non-user-friendly issue still ongoing until now.

\section{Methodology}

A local review of existing guidelines: Towards Design Guideline of Ablution Spaces

This section of the paper highlights several local solutions and more importantly, a survey done directly to assess and gauge users' responses to the ablution provisions. Mokhtar "Design Guidelines for Ablution Spaces in Mosques and Islamic Praying Facilities" for example, established four models as a conventional design guideline for ablution area. He was mentioned in his article title 'Design Guidelines for Ablution Spaces in Mosques and Islamic Praying Facilities' that "there are no design guidelines that help designers provide users with safe and comfortable ablution spaces. Consequently, the quality of the design depends heavily on the designer's ability to understand and familiarize himself/herself with the function of the space and his/her willingness to invest time in investigating various design alternatives." Thus, he was come out with these models in order to provide a design data for other designer and developer to refer.

Before focusing on the design guideline, Mokhtar "Design Guidelines for Ablution Spaces in Mosques and Islamic Praying Facilities" was listed the requirements including religious guidelines and functional space that determine the design of the ablution workstation:

1. Water that will be used for ablution purposes should be clean and fresh. User cannot use the same water that already been used by the previous person. The unit that apply storing amount of water that can be used by the same peson need to be eliminated.

2. While taking a wudu', a user has to use his/her both hands to perform parts of the ablution process such a washing the arms. Thus, the design needs to provide the equipment that avoid user using only one of his/her hand in order to get water flow.

3. Design should be able keep user balanced and comfortable while his/her raise one of feet and at the same time wash it by hand. 
4. Minimum recommendation for horizontal distance between adjacent ablution units is $82 \mathrm{~cm}$ because it should be wide enough while perform ablution without the users hitting one another.

5. The ablution workstation should be secure to reach and leave when in wet feet condition. Mokhtar "Design Guidelines for Ablution Spaces in Mosques and Islamic Praying Facilities" mentioned that design that use a step or carpet that normally found in the ablution area can cause slipping accidents.

6. Elements and areas that hard to be cleaned need to avoid in order to prevent from bacteria growth because of wet surrounding.

7. Users should experience the right posture which not bend their backs or knees for too much. Design need to consider elderly and sick users as well. The accessories such as handrails or shelves should be provided in order to help these users standing and sitting. Shelves and clothes hangers should be provided for hanging the scarf or towel.

8. Design should prevent water reflections on the floor surfaces which end up absorbing on users' clothes. Reduce the wetting on the floor that are in contact with the users.

Based on the guideline given, Mokhtar was prepared several possible model of ablution units (Mokhtar "Design Guidelines for Ablution Spaces in Mosques and Islamic Praying Facilities").

\section{Model 1}

Model in fig. 7 was designed with seat provision user. He/she can perform the wudu' process while seated. Mokhtar also provided a preferences dimensions for an ergonomic workstation in model 1 (Mokhtar "Design Guidelines for Ablution Spaces in Mosques and Islamic Praying Facilities"). There are also design consideration that need to be followed:

1. Seat with an octagonal shape is easier to be access by the user.

2. The location of seat base is at the same platform as approaching floor, so that user can avoid from slipping while they are changing the levels.

3. Anti-slippery material needs to be covered on the approaching floor and the material should allow water to flow to the drainage provided.

4. Covering the water drainage channel with a mesh for safety purposes. The mesh needs to has wide openings around $5 \mathrm{~cm}$, so it will not collect human output especially from sniffing.

5. Provide a shelf in workstation, so that user can put their personal materials such as hand watches, eye glasses, and handbag.

6. $45^{\circ}$ tilt is formed in the facing wall in order to enable users put their feet away from the water drainage.

7. The seat surface needs to be slightly sloped, so that the scattered water that splash on the surface will allowed to drain towards the drainage as make the seat fastly dried. 
8. The seat should use the suitable color and pattern in order to easily notice if the seat is wet or dry. Mokhtar (2005) was not recommended granite material because this material always cause wetting the clothes.

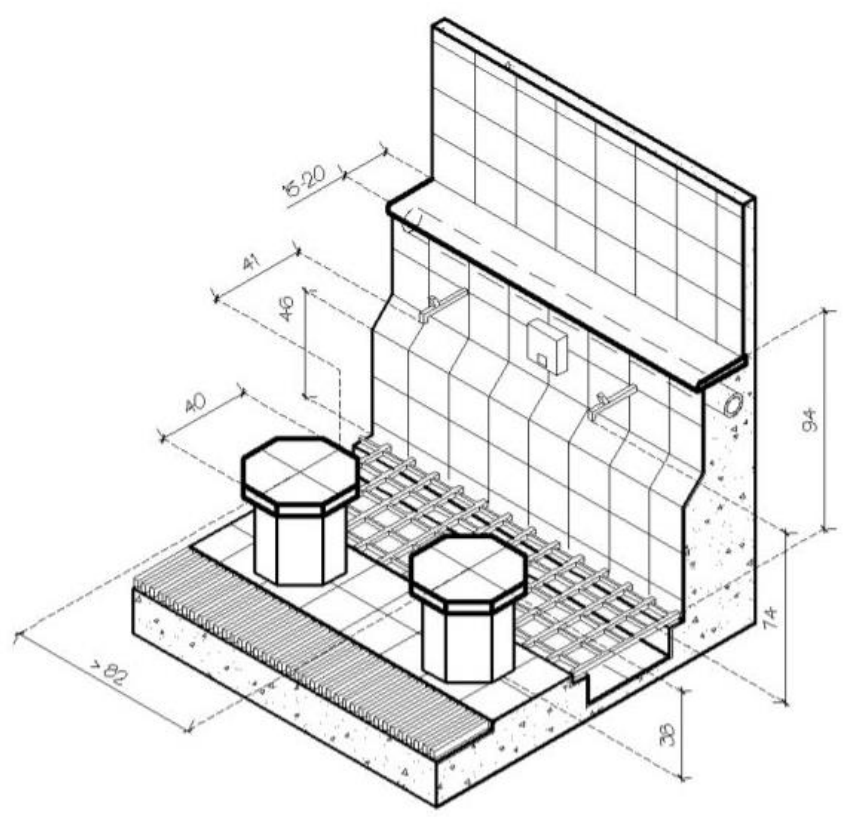

Fig. 7 Design guideline for model 1 by Mokhtar

(Mokhtar "Design Guidelines for Ablution Spaces in Mosques and Islamic Praying Facilities")

\section{Model 2}

For model 2 (shown in Fig. 8) was proposed by included a lavatory which most of the Muslim use it in their homes to perform ablution. The preferred dimensions were provided in this model design. But the highlighted problem while using this model is that the users may not experience a right posture which they need to bend their back to the lavatory and they also need to raise their feet until reach the faucet level. Mokhtar "Design Guidelines for Ablution Spaces in Mosques and Islamic Praying Facilities" then was prepared a proper dimension in order to solve this problem. He settled the issue by lowering the lavatory level and raising the faucet level. He also claimed that the provided dimensions were not suitable for wheelchair users. According to him, Al Sheebany mentioned that "At least one lavatory that satisfies the required dimensions for those users should be provided. Normally, people expectation while lavatories were used in public space represents as maintenance problem. This kind of issue will be more obvious if it is related to the ablution area. The cleanliness of lavatories needs to be kept always, so users will feel more comfortable to use the space for ablution process. This model requires a high maintenance cost. Thus, the management of mosques that serving a large number of people need to operate within a very low operating budget. 


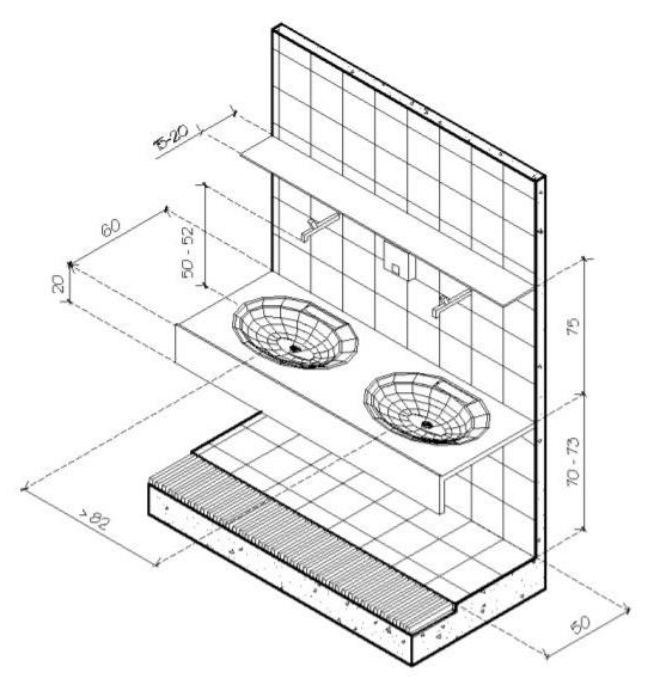

Fig. 8 Design guideline for model 2 by Mokhtar

(Mokhtar "Design Guidelines for Ablution Spaces in Mosques and Islamic Praying Facilities")

\section{Model 3}

Model 3 (shown in Fig. 9) only has a few elements. The preferred dimension for this model was stated in the figure below. For this model, it is provided a shelf for users in order they need a support for their bodies and also, they can put their belongings in the shelf. Mokhtar stated that, this model is very uncomfortable one to use but this model requires a low cost. Users may also experience a bad posture because this model requires the user to sturdily bend their back or knees (Mokhtar "Design Guidelines for Ablution Spaces in Mosques and Islamic Praying Facilities").

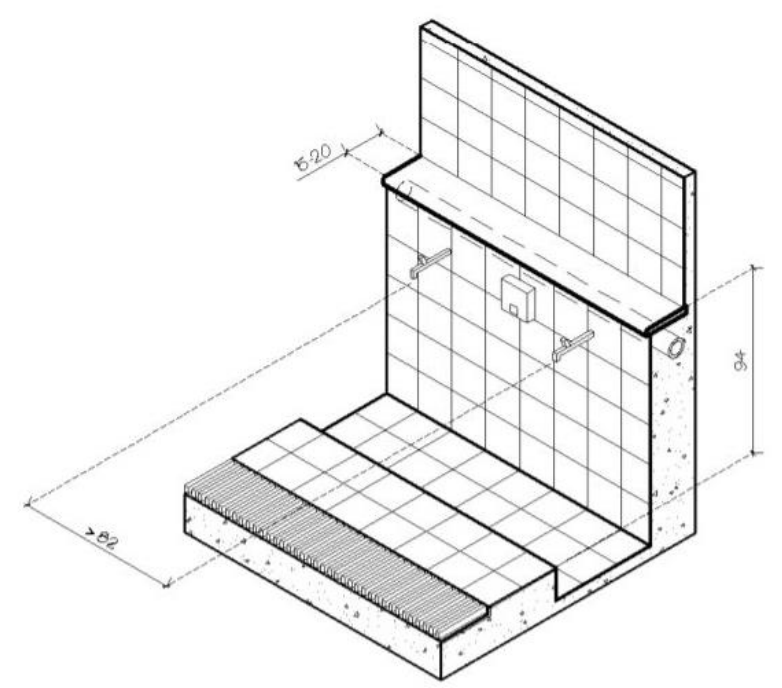

Fig. 9 Design guideline for model 3 by Mokhtar

(Mokhtar "Design Guidelines for Ablution Spaces in Mosques and Islamic Praying Facilities") 


\section{Model 4}

For model 4 (shown in Fig. 10), the design only takes the small part in plan. The model was presented with a proportion dimension. This design requires user to stand in front of barrier. The height of water faucet is higher than usual design in order to reduce the back bending and bad posture. This design also provided a shelf for the users to support their body while having ablution process and also, they can put their belongings there. The approaching floor should be avoided from slipping. This model seems to be very comfortable for the users instead of simple and low cost required. Besides, users should experience minimal wet clothes especially for thoses that wearing skirt-like closes. But this model is rarely specified by designers.

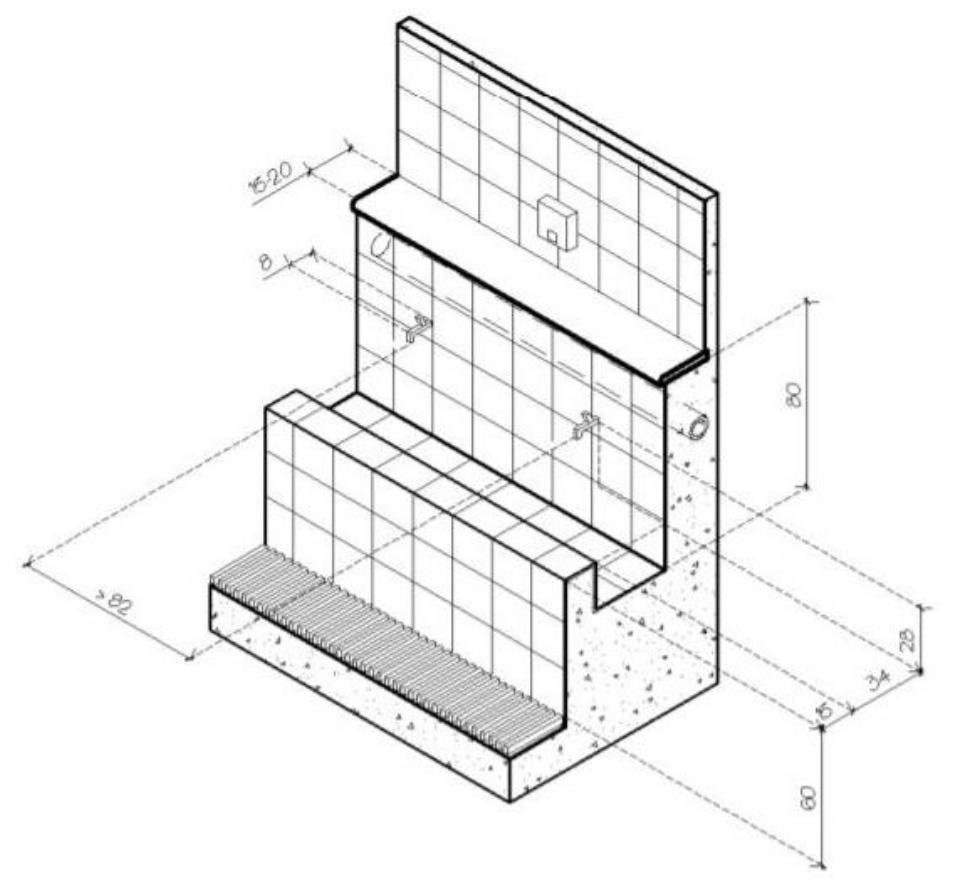

Fig. 10 Design guideline for model 3 by Mokhtar

(Mokhtar "Design Guidelines for Ablution Spaces in Mosques and Islamic Praying Facilities")

At the same time, there are design guideline proposed by Nashirudin and Jasmi. He stated that design of ablution area needs to have 3 differents aspects including;

1. Relation of anthropometric with the location

2. Area segregation

3. Ablution area

The first aspect is more related to the ergonomic study and user-friendly design. Thus, designer needs to focus while designing an ablution area for each level and following the design data that preferred by users especially for special users such as elderly and disabled people. Second guideline was referring to the privacy of the users. The ablution units need to be built separatedly for male and female users. He also recommended to put the position of ablution area by following the 'Qiblah'. There are three area segregation that need to be focused which; wet area, dry or wet area and dry 
area. This segregation is to make sure the cleanliness and the safety of the workstation. Last aspect which is related to the ablution area. This aspect is to highlight the selection of location such as a distance of users and water faucet, a height of water faucet and also the water performance. "This aspect also has strong relation with the ergonomic study" (Abdul Rahman et al.). They also mentioned that Nashiruddin suggested designer to be very detail and focus on the water performance because this problem will cause wet clothes of users while they performing the ablution process (Nashirudin and Jasmi). Che Haliza binti Che Roza (in Abdul Rahman et al.) stated that users normally have a low awareness while using the water because they tend to have excess water usage during the ablution process. Zaini Ujang also suggested an innovation of drainage system by providing the automatic faucet use in ablution platform (Abdul Rahman et al.). "In Islam, Muslim should use only 1 'mud' / $500 \mathrm{ml}$ water for ablution to avoid excess usage of water. Although various studies have been done previously, there are many mosques

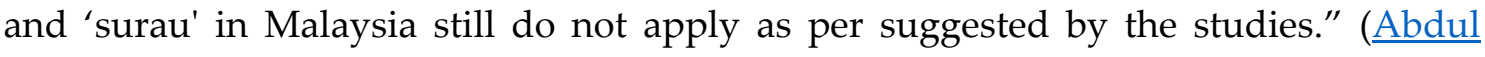
Rahman et al.). They also continued, this issue become less aware in our community due to the lack of information, and also less budget for ablution renovation. Thus, by following the guidelines that had been proposed by the experts, designer should be more aware on the preferences of users for this ablution design units. The design data that already been collected should be implemented and developed into the future project. Therefore, ablution area will be one of the best facilities with an ergonomic and safety system and benefit for all users including elderly and people with disabled (PWDs) (Abdul Rahman et al.).

On site mesurements and surveys of selected sites.

This study was conducted by two stages. First stage, the measurement of ablution area was taken by using manual tool which is measuring tape. The anthropometric dimensions were taken from three different mosques which are Masjid UNiSZA (Universiti Sultan Zainal Abidin), Masjid UMT (Universiti Malaysia Terengganu) and Masjid Tok Jembal. The existing ablution area will be converted into 2D measured drawing properly. For the second stage, the interview was been conducted around 10 repondents from these mosques. Each mosque represents a different data since the design of each mosque is different. The respondents were taken from age $30-65$ years old. The data will be summarize based on the satisfaction from respondents towards the existing design of the particular ablution areas. As been suggested by Hashim (in Dawal et al.), the relevant anthropometry dimension needs to be taken from previous study for user-friendly design of domestic furniture and appliances in order to provide ergonomic dimensions for new ablution unit. Besides, the results from different study that had been done previously by experts also will be analyse and compare with the outcome from this study. This method is to analyse whether the existing ablution areas from these three mosques in Kuala Nerus are following the user's preferences or vice versa. 


\section{Result and Discussion}

\section{Dimension of Ablution Area}

Dimensions of three exsting ablution areas (shown in fig. 11, fig. 12 and fig. 13) from Masjid UNiSZA, Masjid UMT and Masjid Tok Jembal were taken properly using measuring tool. The measured parts including height of water faucet from the bottom and platform, distance between water faucet and user, seat provision's size and platform area.

\section{Masjid UNiSZA (Universiti Sultan Zainal Abidin)}

Masjid UNiSZA was located inside of the campus UNiSZA. This mosque is place in Gong Badak, Kuala Nerus, Terengganu. This mosque has two levels. Normally the second level will be open while performing jumaah congregational prayer and eids congregational prayer. This mosque was opened in $20^{\text {th }}$ August 1993 and launched by Sultan of Terengganu at that time. Because of the mosque is already age more than two decades, the design standard at that time was not been focused like nowadays. The design of existing ablution units mostly from the beginning of the construction began. The proportion of the preferred dimensions quite poor rather than the present mosques. From the dimension illustrated below, the height of water faucet from the ground is only $65 \mathrm{~cm}$. Meaning that, if user standing on the platform provided, the height of water faucet become less than that, which around $51 \mathrm{~cm}$ only. Some of the user preffered to bend their knees while taking the ablution process. It is because that way is much better than bending their back to reach a water faucet. The distance between water faucet and the users seems well proportion and less water splash on the user's shirts.

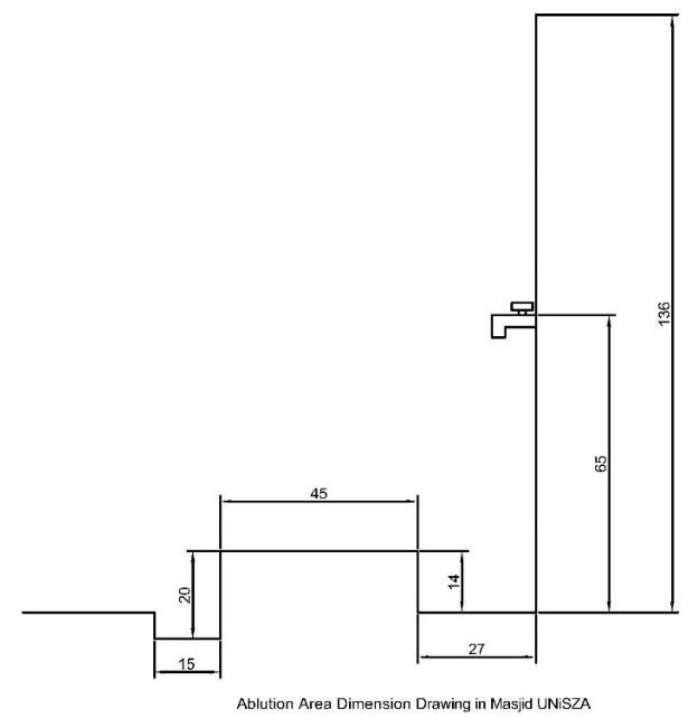

Fig. 11 Dimensions of ablution area in Masjid UNiSZA (source: author) 


\section{Interview data}

From the interview that had been conducted in this mosque, some of the user less satisfied with the existing of the ablution area. Respondent name Abdullah, age 65 stated that, he always experiences back ache while performing the ablution process. The water faucet is too low for him. For an elderly like him, he having a bad experience in this design. He also said that the higher water faucet would be better for him as an elderly. Eventhough there is no seat provided, he still not preferred to be seated because the distance between water faucet and seat will cause the water splash too much on his shirt. He preferred to standing while taking an ablution process. Besides, another respondent also mentioned that normally the users are coming from middle age and young age such as students from UNiSZA and lecturers. Therefore, this kind of proportion can be overcome by these groups because they might not experience the back ache like elderly people.

\section{Masjid UMT (Universiti Malaysia Terengganu)}

Masjid UMT or Pusat Islam Sultan Mahmud was starting their operation since $1^{\text {st }}$ April 2016. In this mosque the height was in average state. It is one of the administrative centers housed under the UMT Chancellor. Same with the Masjid UNiSZA, most of the users of Masjid UMT are among the students and lecterers. But they also opened to the public especially while performing jumaah congregational prayer. The design of the ablution workstation in this mosque (shown in fig. 12) is better than previous case study which is Masjid UNiSZA. This is because Masjid UMT was already exposed to the design data that had been establish by few experts. Yet, there are also some deficiency in term of the selction of water faucet design. The design of water faucet is long-necked water faucet which reduce the space between the users and water faucet. Unfortunately, this water faucet can be adjusted into different directions (left and right) as what user preferences. The height of the water faucet from the platform is $64 \mathrm{~cm}$ which according to design guideline from Mokhtar, it is still lower for the users. In this area, there was a provided a carpet in order to avoide a slippery. The carpet was in a good condition which it can avoind slipping for the users.

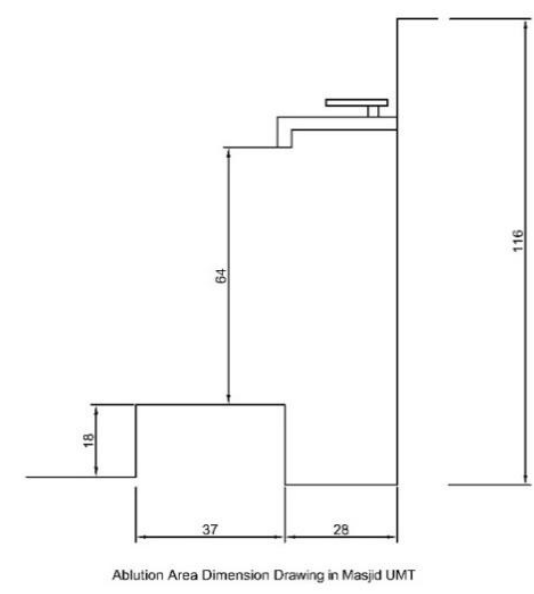

Fig. 12 Dimensions of ablution area in Masjid UMT (source: author) 


\section{Interview data}

The results of interview show that some of the respondents in Masjid UMT does not aware on the issue that occurred there. They simply satisfied with the facilities provided. But some other respondents agreed that they need to bend their back while performing the ablution process. They said, "maybe for people that is shorter height doesn't have problem, but other with higher height need to bend their back or knees". Even though there is no seat provided, but the design accommodates the mini shelves on top of the water faucet, so users can grab the shelves if they are having imbalanced while they lift up one foot and wash it by another hand. Regarding with the issue of wet flooring, the respondent satisfied with the condition because there is carpet provided to avoid slippering. Besides, the cleanliness also has been taking care by the administratives in order to make sure the users feel comfortable while taking the ablution.

\section{Masjid Tok Jembal}

Masjid Tok Jembal was finish the construction period in year 2010. This mosque is located in Kampung Tok Jembal which is near to the other two case study. The mosque was opened for the public or villagers for jumaah congregational prayer as well. The users normally among the middle and elderly people. Interestingly, the design of the ablution area was satisfied. The height of the water faucet from the ground floor is $110 \mathrm{~cm}$ while from the platfrom, the height is $90 \mathrm{~cm}$. The height is quite proportion and users doesn't require to bend their back too much and their knees as well. They also provided ablution half wall with water fitting, so that the water will flow directly into the drainage and users will less experience in water splash to their clothes.

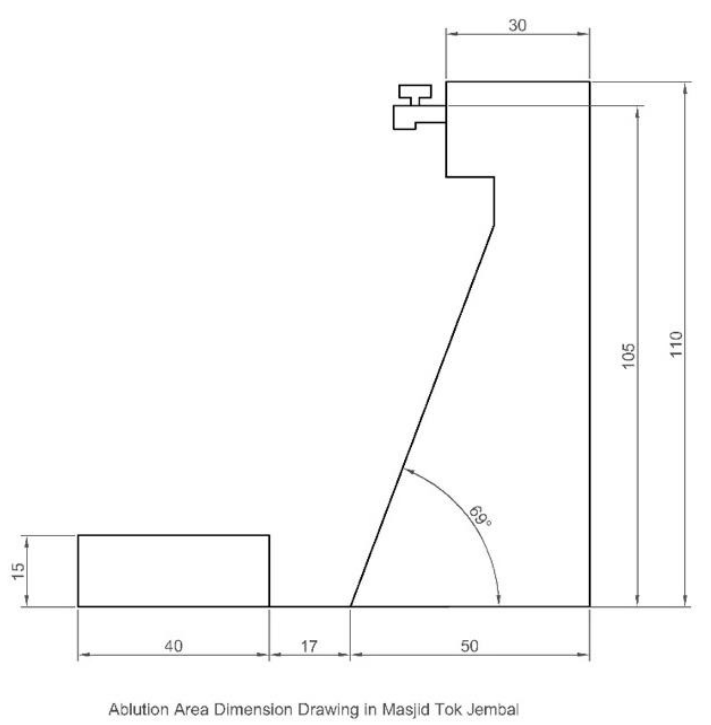

Fig. 13 Dimensions of ablution area in Masjid Tok Jembal (source: author)

\section{Interview data}

From the conducted interview, most of the respondent satisfied with the design provided in this mosque. They don't experience the bad posture while performing the ablution process. Besides, the condition of the ablution area is very clean. The floor is 
quite slippery when wetting but they provide a wooden platform for the users along the way to main prayer hall.

Table 1 Dimension of Ablution Area Evaluation.

\begin{tabular}{|l|l|c|c|c|}
\hline No. & Dimension & Masjid UNiSZA & Masjid UMT & Masjid Tok Jembal \\
\hline 1 & Seat height & - & - & - \\
\hline 2 & Seat width & - & - & - \\
\hline 3 & Seat length & - & - & - \\
\hline 4 & Tap height & 65 & 82 & 105 \\
\hline 5 & Tap-user distance & 6 & 0 & 30 \\
\hline 6 & Handrail height & - & - & - \\
\hline 7 & Handrail-to-seat distance & - & - & - \\
\hline 8 & Barrier height & - & - & - \\
\hline 9 & Barrier width & - & - & - \\
\hline 10 & Drain width & 27 & 28 & 17 \\
\hline 11 & Barrier-to-user distance & - & - & - \\
\hline 12 & Foot step height & 14 & 18 & 40 \\
\hline 13 & Foot step width (if seat not available) & 45 & 37 & \\
\hline & & & & \\
\hline
\end{tabular}

Source : author.

\section{Conclusion}

This paper highlighted an issue and concern involving ergonomics, which still need more research and guidelines. Reviewing local and international cases, there seem a number of solutions which have been attempted by architrects and researchers, yet which have not be standardized into universal guidelines which are elderly friendly. Yet the number of mosque construction will keep on increasing every year. It is perpendicular to the number raise of elderly and disabled people in community (Dawal et al.). Thus, designer and developer need to tackle the issue and overcome the nonergonomic and non-user-friendly design into a better one. This paper also wants to highlighted about the health issue that has been experience by elderly and also disabled people which this should not be happened in a new development of mosques in Malaysia. From the previous work and guideline given by the experts, it seems that the findings of the study are not fulfilled the requirement of the design baselines. It can be happened due to lack of research before starting the project or also there was lack of guidelines provided from that particular time. Among three case study of the mosques, the most appropriate design of ablution area is Masjid Tok Jembal. This ablution area is one of the demanding designs for users especially elderly people. Meanwhile, another two-case study which is Masjid UNiSZA and Masjid UMT demonstrate the need to improve design based on anthropometric dimensions so that people will be more comfortable while performing the ablution process, particularly these cases highlight the 
need for more handrails. Overall, these three-case studies are in good condition in term of cleanliness. Therefore, hopefully this study could help the public, the authorities and the designers towards designing and universalizing the guidelines of the ablution area and to develop a more -elderly friendly ablution workstation that focus on all type of users in the Muslim ummah and community.

\section{Acknowledgements}

Special thanks to Assoc Prof Dr Puteri Shireen for the review of this paper and for encouraging this interesting topic. The author was inspired as she mentioned that while she was in France for last few years, this topic was the exact one coming in her mind. She also mentioned that the European manufacturers are interesting towards this issue since they do many accessories for the Dubai and Abu Dhabi markets (project and building). This work was educationally supported by the experts that produced their articles and designing the ergonomic ablution area whether in Malaysia and outside from Malaysia.

\section{References}

Abdul Rahman, Julaila et al. "Physical and Safety Features of Ablution Spaces in the Mosques of Selangor and Kuala Lumpur." IOP Conference Series: Materials Science and Engineering, vol. 401, 2018, p. 012020, doi:https://doi.org/10.1088/1757$\underline{899 x / 401 / 1 / 012020 .}$.

Aman, A. et al. "Design and Analysis of Wudu' (Ablution) Workstation for Elderly in Malaysia." IOP Conference Series: Materials Science and Engineering, vol. 210, 2017, p. 012069, doi:https://doi.org/10.1088/1757-899x/210/1/012069.

Besari, Adnan Rachmat Anom et al. "Automatic Ablution Machine Using Vision Sensor." 2009 IEEE Symposium on Industrial Electronics \& Applications, vol. 1, 4-6 Oct. 2009 2009, pp. 506-509. doi:10.1109/ISIEA.2009.5356425.

Dawal, Siti Zawiah et al. "Wudu'workstation Design for Elderly and Disabled People in Malaysia's Mosques." IRANIAN JOURNAL OF PUBLIC HEALTH, vol. 45, no. Supplement 1, 2016, https://www.sid.ir/en/Journal/ViewPaper.aspx?ID=489352.

Fitzpatrick, Robert B. "Americans with Disabilities Act of 1990." Journal of the National Association of Administrative Law Judiciary, vol. 11, 1991, pp. 13-24.

Mokhtar, Ahmed. "Design Guidelines for Ablution Spaces in Mosques and Islamic Praying Facilities." Journal of Architectural Engineering, American Society of Civil Engineers, 2005, pp. 3-9. 
Sarah Aliya Che Hasbi \& Sufian Hamat (@ 2020)

---. "Design Standards for Muslim Prayer Facilities within Public Buildings." Annual Research Conference of The Architectural Research Centers Consortium: Leadership in Architectural Research, Between Academia and The Profession, Architectural Research Centers Consortium (ARCC), 2009, pp. 163-169.

Nashirudin, M A S and K A Jasmi. "Cadangan Penyediaan Tempat Wuduk Yang Efisien." Pengurusan Berkualiti Memacu Kecemerlangan Pengurusan Masjid, UTM Press, 2008, pp. 124-140.

Pel-Ona Architects \& Urbanists. "Beccc Mosque." Pel-Ona.com, 2020.

UN World Population Prospects. "Malaysia Population 2020." 2020. 